\title{
APLICAÇÃO INTEGRADA DE MÉTODOS GEOFÍSICOS EM ÁREA DE DISPOSIÇÃO DE RESÍDUOS SÓLIDOS URBANOS EM BAURU-SP
}

\author{
Alexandre Lisboa Lago \\ Orientador: Dr. Vagner Roberto Elis (IAG/USP) \\ 110 p + anexos - Dissertação (Mestrado) - Defesa 03.02.2004
}

\begin{abstract}
RESUMO. 0 presente trabalho tem por objetivo a aplicação integrada de metodologias geofísicas visando a caracterização geoelétrica da área utilizada para disposição de resíduos sólidos urbanos na cidade de Bauru-SP. Para estudar o local e avaliar a existência do problema da contaminação foram utilizados os métodos geofísicos da eletrorresistividade, polarização induzida e potencial espontâneo. 0 Aterro Sanitário, geologicalmente, está posicionado sobre área de afloramento de arenitos do Grupo Bauru. Este atributo litológico é considerado impróprio para implantação desse tipo de empreendimento, segundo Zuquette et al. (1994). 0 Inventário Estadual de Resíduos Sólidos Domiciliares de 2002, apresentado pela Companhia de Tecnologia de Saneamento Ambiental-CETESB, enquadra como adequada a instalação de destinação de resíduos sólidos urbanos na cidade de Bauru. Os métodos da eletrorresistividade e polarização induzida permitiram identificar anomalias, dentro da zona saturada, que caracterizam a presença da contaminação gerada pela migração do percolado proveniente da cava preenchida com resíduos. Essa contaminação é confirmada pelos métodos de investigação direta (análise da água coletada nos poços de monitoramento permanente e sondagens de piezocone de resistividade). 0 grande intervalo de variação dos valores de potencial espontâneo intensa atividade geoquímica na área de estudo. Os métodos geofísicos utilizados forneceram um grande número de informações sobre as diversas características relacionadas à intenção entre a área de disposição de resíduos sólidos urbanos e 0 meio físico.
\end{abstract}

ABSTRACT. The aim of the present work is to perform geoelectric characterization of an urban solid waste disposal area placed in Bauru city, São Paulo state, through integrated application of geophysical methodologies. The employed geophysical methods were eletroresistivity, induced polarization and self-potential, for studies concerning to contamination problem and area survey evaluation. The Landfill is geological placed on sandstone outcrops from Bauru Group Zuquette et. al. (1994) reported that this lithologic context is not adequate to the implementation of this kind of undertaking. Nevertheless, the State Relatory of Solid Waste (2002), which was done by Companhia de Tecnologia de Saneamento Ambiental- CETESB - fall under adequate the embankment install in Bauru city. Either eletroresistivity and induced polarization methods allow to identify anomalies inside the saturated zone, which characterized the contamination presence generated by percolated from digging, filled up with waste. Contamination is revealed through straight investigation methods (analysis of water collected from manhole and resistivity piezocone sounding). The large variation interval of self-potential values pointed to intensive geochemical activity at the studied area. As a matter of fact, geophysical methods employed in this work provided a considerable amount of informations among several characters related to interaction between urban solid waste disposal area and environment. 